\section{Why scientific practices are not included in Science lessons? What does it go unnoticed for What does it go unnoticed for
teachers}

\author{
teachers
}

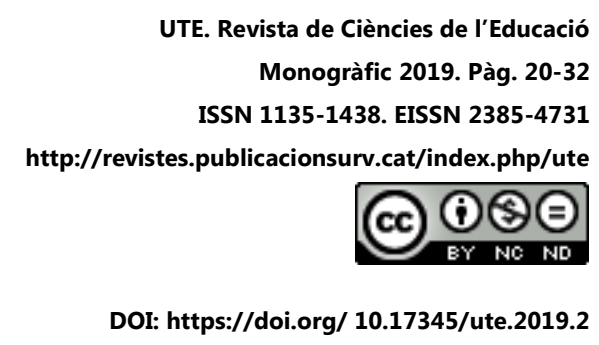

\author{
María Rut Jiménez-Liso $\mathbb{D}^{-}$, Ana Amat González $\mathbb{D}^{D}$, María Martínez-Chico $\mathbb{D}^{-}$, Jose Miguel \\ Vílchez González (D), Rafael López-Gay Lucio-Villegas
}

Rebut: 31/05/2019 Acceptat: 03/10/2019

\begin{abstract}
Despite the importance that research gives to including scientific practices in science education, it has been reported a lack of effectiveness of the approaches adopted in science classrooms. The efforts made in promoting inquiry-based learning seem not to have been very successful, taking into consideration the current dissatisfaction with the inadequate interpretation of these approaches.

This paper attempts to address the issue of the lack of proper scientific practices as shown in the results of a range of research projects and their implications for teacher training, by addressing the following issues: Reasons why the scientific practices are not included in science lessons; the purposes or advantages served by the use of scientific teaching practices in classrooms and how they influence the instruction; the importance of recognising emotions felt in science classrooms; and how to reach competent science teachers who know, not only how to introduce scientific practices properly in their instruction, but also understand why such practices are necessary in relation to the epistemic knowledge.

With the aim of making future teachers aware of the scientific practices' advantages, we propose to promote the opportunity of experiencing the implementation of Model-Based Inquiry sequences with SENSe, SENSors, and SENSations, in their classes with their own students.
\end{abstract}

Keywords: Scientific practices, In-service Secondary teachers' perceptions, Inquiry-based learning, Teacher training.

\title{
Resumen
}

A pesar de la importancia que la investigación otorga a introducir prácticas científicas en las clases de ciencia, numerosos informes señalan su ausencia o escasez en los niveles de Primaria o Secundaria. Los esfuerzos realizados en promover el aprendizaje basado en la investigación parecen no haber tenido mucho éxito, teniendo en cuenta la actual insatisfacción con la interpretación inadecuada que se hace de este enfoque.

En este artículo queremos abordar el problema de la falta de prácticas científicas adecuadas en las aulas de ciencias profundizando en cuál puede ser la causa de su escasez desde las opiniones de docentes en 
activo. En concreto, le preguntamos a sesenta docentes participantes en cursos de formación permanente sobre utilización de sensores, ¿qué propósitos o ventajas consideraban que tenían las prácticas científicas en sus aulas y cómo influyen en su instrucción? Tras este primer sondeo, entrevistamos a un docente que desarrollaba habitualmente prácticas científicas sobre la importancia de reconocerlas con el objetivo de cómo llegar a ser profesores de ciencias competentes que saben, no solo cómo introducir prácticas científicas correctamente en su instrucción, sino también entender por qué son necesarias, en relación con el conocimiento epistémico.

Con el objetivo de que los futuros maestros tomen conciencia de las ventajas de las prácticas científicas, proponemos facilitar el acceso a secuencias cortas de indagación por modelos, diseñadas con el objetivo de que tengan Sentido, usen sensores y tomen conciencia de las sensaciones que produce a sus propios estudiantes.

Palabras clave: Prácticas científicas, Percepción de los profesores de Secundaria en activo, Enfoque de enseñanza por indagación, Formación permanente del profesorado.

\section{Introduction}

Considering science learning as a participation in the scientific practices is a framework that is gaining momentum in educational research. We understand these practices in relation to what meant by "inquiry" in science and the range of cognitive, social, and physical practices that it requires is explained by National Research Council (2012): Asking and refine questions; developing and using models for representing ideas and explanations; planning and carrying out systematic investigations; using mathematical thinking; constructing explanations; engaging in argument from evidence; obtaining, evaluating, and communicating information, criticising and communicating ideas individually and in groups. In the European scene, the contemplation of scientific competencies in Science Education for Responsible Citizenship reflects a view of science as an assemble of social and epistemic practices, considering what scientifically literate person understands and is capable of doing (Hazelkorn et al., 2015). This new paradigm emerges given the need to overcome the current science education in schools focused on a set of products rather than on the processes of science (Duschl \& Grandy, 2013), and to address the teachers' misunderstandings of the goal of engaging in inquiry as they don't consider the importance of understanding the whole process of inquiry, which leads teachers to focus on manipulative skills and cookbook laboratory exercises (Osborne, 2014) when they try to introduce some innovations in their instruction.

This suggests that there is needed to re-interpret science teaching and improve it, with the aim of reaching effective scientific practices in classrooms, by considering the continuous connections between phenomena and the theoretical or matter subject contents.

This paper attempts to address the issue, identified in the results of various research projects, of the lack of proper scientific practices in Science classrooms and the implications for teacher training, by addressing the linked research question: Why scientific practices are not included in science lessons?

To address this question, firstly, we try to deepen the perceptions of in-service teachers about practical works (terminology commonly used among secondary school staff), through the implementation of a questionnaire and the conduct of an interview. To advance in the search of solutions for the presented problem we address a teacher training proposal focused on showing evidence to in-service teachers of 
the scientific practices' effectiveness with regard to science learning and motivation on their own students.

\section{Why are scientific practices not included in science lessons?}

In this section the research design is presented chronologically, as the results and research considerations and decisions are linked, this presentation format makes more sense than the classical one of separating the methodology, the results and the analysis. Thereby, the first section focuses on a questionnaire that was implemented with in-service teachers participating in a training course. After analysing the results obtained, one of them was selected to be interviewed, and then, we recorded his science classes (about Boyle's law) to check if there were coincidences between his instructions and what he declared.

Regarding the sample, all teachers participating in this study are in-service Secondary School teachers, who have more than 15 years of teaching experience (some of them even about 30 years). More than half (60\%) of the participating teachers were women, although no gender-differentiated study was done.

As it will be seen along the paper, we will refer to the same term using different ways of calling it, something we want to clarify that in text. We (researchers and authors) analyse teaching-learning from the prism of 'scientific practices' (considering these not only as hands on activities, but also as minds on activities). However, to adapt ourselves to the usual jargon of Secondary School teachers that we have worked with, both in this (the participating teachers) and in other previous experiences, the expression 'practical works' has been the one used. Furthermore, it must be known that the teachers participating in this study, both, the group of teachers when initially were asked and the teacher interviewed and recorded, manifest that interpret these practices mainly as hands on activities or manipulative activities, leaving out minds on activities.

\subsection{Questionnaire: Motivation vs. curricular pressure}

Different researchers (Ebenezer, Kaya \& Ebenezer, 2011) and reports on the state of science education in the educational context of the future (Rocard, Csermely, Jorde, Walberg-Henriksson \& Hemmo, 2007) indicate that the time spent on practical work is virtually non-existent in primary education and that it is reduced drastically in secondary education; it becomes almost non-existent, and Spain is no exception to this trend (Confederación de Sociedades Científicas de España, 2011). The causes have been identified and range from the many difficulties encountered by teachers with laboratory activities in their science classrooms (Boujaoude and Jurdak, 2010; Holstermann, Grube \& Bögeholz, 2010) until others related to the available time, e.g.: High student/teacher ratios, material shortages, curricular pressure (too much theoretical content in a short time), overloaded timetable, insecurity, the usual lacks in professional development, the lack of good models and definitions for what inquiry-based teaching actually means, and the lack of good resources enabling the ability to change. The importance of investigating the teachers' conceptions and perceptions and how they affect the professional development processes of the teaching staff is justified for various reasons: the effects of prior beliefs are crucial to the acquisition of new knowledge; and teachers rarely have the opportunity to reflect, discuss and reconsider their beliefs during training courses (Correia $\&$ Freire, 2016). In this sense, the first part of this study explores in-service teachers' perceptions on practical works in science teaching and the relationship between such perceptions and their actual instruction.

In a previous research (Pino Álvarez, Jiménez Valladares, Jiménez Liso \& Sampedro Villasán, 2012), our aim was to verify if these difficulties are offset by the benefits of developing scientific practices. 
Considering this, we asked a group of in-service high school teachers (60) who were participating in a training course on the use of sensors in science classes, to answer a questionnaire on purposes, advantages and disadvantages of practical work. Specifically, we asked them about the importance they attached to practical work in their own classrooms with the following question.

'Which of the following factors, do you think that are more important to promoted by practical work?' (1-9 indicate the order of priority of these factors):

- Improve student motivation (Motivation).

- Allow a more direct relationship with everyday phenomena (Related Phenomena).

- Promote the formulation of students' questions (Questioning).

- Allow the construction of theoretical models and their immediate experimental testing (Models).

- Encourage students to predict the outcomes they expect (Results Prediction).

- Promote understanding of scientific concepts (Contents Understanding).

- Help to introduce data analysis techniques (Data Analysis).

- Allow students to approach the methodology and procedures of scientific inquiry (Scientific Methodology).

- They provide an opportunity for teamwork and development of cooperative attitudes (Teamwork)

The responses have been grouped by the value given in the questionnaire, using a Likert scale: 1 to 3 as 'Very Important', 4 to 6 as 'Important' and 7 to 9 as 'Unimportant'.

\subsection{Questionnaire Results}

Firstly, the results about the previous question (Figure 1) show that the participating teachers $(\mathrm{N}=60)$ declare motivation as the most important aspect of practical work (62.26\% very important), while the use of models is the aspect that was awarded lower importance (10\% very important or unimportant $40 \%)$. 


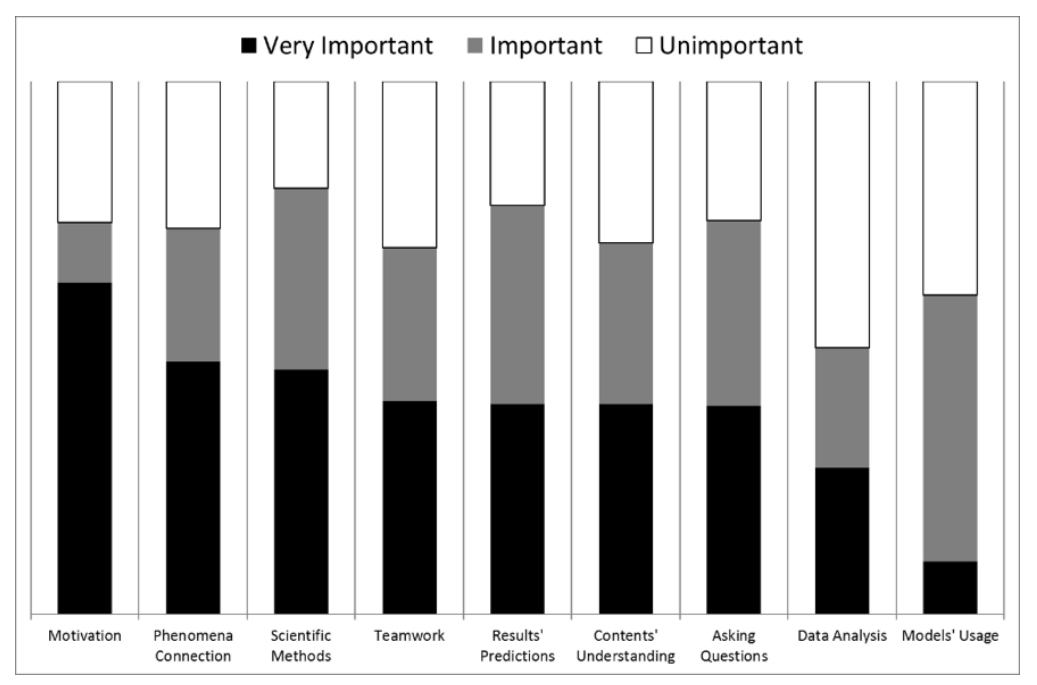

Figure 1. Importance that teachers attach to the purpose of practical work

This made us question the reason why practical works are so scarce in science classes: is promoting students' motivation a sufficiently strong factor when weighed against the found difficulties (ratio, time limitations, safety, lack of materials, and, above all, the curricular pressure)? Or, on the contrary, it is precisely the little importance given to the connexion between models and practical works one of the causes of the practical work shortage in science lessons? According to these considerations, it makes sense, that the few attempts of teachers to introduce practical work in their science lessons are limited to some hands-on activities, leaving out others that require greater cognitive effort, such as models (Ateş \& Eryilmaz, 2011). Or on the other hand, it is also possible that if those teachers who routinely perform practical work (overcoming these difficulties) find in practical work other purposes that go unnoticed for them and therefore are not reported as important in the questionnaire as worthy of mention.

\subsection{Interview outcomes: Scientific practices just to motivate, unnoticed learning models}

To deepen activities that the teachers usually do and how they perceive them (for what purpose are performed), we selected one of the teachers who regularly develops practices in his secondary science lessons and who had selected motivation as a very important reason and learning models as less important and interviewed him. During the interview before the recording he insisted on the advantages he found in doing practical work in the laboratory:

It allows me to capture more of the student's attention, I try to capture the student's attention and to let them see in practice what I am explaining in theory, they retain this knowledge better [...] learning is much more effective [...] more significant for them.

In this interview we also asked about his standard lesson plan to raise his instruction, and again, using models or modelling was not on it:

The first thing is to ask what you intend to prove with the practical work, what is the problem you are posing, what questions you are going to answer [...]. Secondly, a series of hypotheses for the problem stated are formulated. Then we try to contrast these hypotheses designing experiences or even searching the literature about that experience to design and implement the experience. And finally, we contrast these hypotheses by experiments, to see if that hypothesis was true or not, if it is valid, perfect, and we will see from that experience more questions can crop up giving rise to other problems, because maybe we did a variables control which then makes us wonder if we had changed the variable what would happen ... it can promote new research; and if it is not valid, we start again developing new hypotheses. 


\subsection{Video recording teacher's class about Boyle's law of gases}

The teacher who was recorded was previously interviewed and that was when he was asked about his availability and willingness to be recorded, the class he preferred. The first class indicated was one lecturing type, focused on the explanation of the gas law and molecular kinetic theory, using power point presentations and the blackboard to solve student doubts. The scheme of the second class (in the laboratory) is described in table 1 where he raised the practical work (with a paper-guide for students) and doubts were resolved, for example, when choosing the function that describes the data dispersion obtained with the sensors.

In the interview, the teacher confirms and declares the importance of capturing the attention of students, but does not state that he makes use of models, so, to see if they play a role in his classes, we recorded the complete practical experience of the experimental determination of Boyle's law of gases, developed in two sessions in the laboratory and in a lecture lesson (3h). We grouped the activities and identified the teacher and students' interventions, counting the time the class spent on each fragment (analysed with Atlas.ti, Table 1).

Table 1: Timing of classroom activities

\begin{tabular}{ccc}
\hline Activities & Teacher speech & Students speech \\
\hline Explore a situation & $1^{\prime} 25^{\prime \prime}$ & 0 \\
Predicting data and graphics to be obtained & $3^{\prime} 30^{\prime \prime}$ & $9^{\prime} 5^{\prime \prime}$ \\
Perform data collection & $3^{\prime} 30^{\prime \prime}$ & $12^{\prime}$ \\
Analyse and interpret the results (Model) & $19^{\prime} 40^{\prime \prime}$ & $29^{\prime} 40^{\prime \prime}$ \\
Restructure new knowledge (Model) & $7^{\prime} 35^{\prime \prime}$ & $11^{\prime} 35^{\prime \prime}$ \\
TOTAL & $35^{\prime} 40^{\prime \prime}$ & $1 \mathrm{~h} 2^{\prime} 20^{\prime \prime}$
\end{tabular}

From the time that each participant became involved in the activities (Table 1), we can deduce that a third of the 3 hours corresponds to interventions of students ( $\left.1 \mathrm{hr} 2^{\prime} 20^{\prime \prime}\right)$ while the time of teacher intervention is reduced to $35^{\prime} 40^{\prime \prime}$. These first data indicate that the classes are not transmissive (focused on teacher speech), but that the students' communication is a priority. If we analyse the duration of the intervention of students depending on what they do and what they say, for $29^{\prime} 40^{\prime \prime}$ they are analysing and interpreting results using the Molecular Kinetic Theory as a model, and for $11^{\prime} 35^{\prime \prime}$ they are evaluating the model and changing it to construct new knowledge. Therefore, for most of the students' intervention time $\left(41^{\prime} 15^{\prime \prime}\right)$ they are using a model to solve the problem posed.

From this teacher perception, the theoretical and practical connection has not gone unnoticed and he considers it to be the purpose of practical work. However, he is mainly concerned with the motivation that hands-on activities produce, without considering the role in explaining, using and reviewing models; so that when these activities cease to be "motivating", curricular pressure could make him reduce the practical content of his lessons.

As teachers take models and modelling for granted, motivation becomes the only emotion demanded by teachers. The importance of emotions in both cognitive and affective processes is one of the aspects 
of conceptual change (Thagard, 2008) and thus, as stated Mellado et al. (2014), the teachers who ignore these affective aspects may be limiting conceptual change in their students. As Nicolaou, Evagorou and Lymbouridou (2015) report, the majority of studies in the field of science education report that positive emotions and enjoyment from learning science play a significant role in learning outcomes and serve as a driving force for self-learning, and for retaining knowledge (Alsop \& Watts, 2003). Nevertheless, the analysis of students' emotions about learning science through participating in authentic contexts is still scarce, even though we are aware that students' emotions, either positive or negative, can have a significant impact on learning (Dávila Acedo, Borrachero Cortés, Cañada Cañada, Martínez Borreguero \& Sánchez Martín, 2015; Evagorou, Nicolaou \& Lymbouridou, 2014).

According to Mellado et al. (2014) we are aware that a relevant intervention is not synonymous with success if these emotions are not identified, and it may be that, as with knowledge, different emotions go unnoticed, leading to negative attitudes and even to rejection of science. Therefore, we understand that science learning should also produce emotions; it may produce to a greater or lesser extent: shame, insecurity, interest, satisfaction, etc.

\section{A proposal to make teachers aware of the advantages of scientific practices and promote their integration into their instruction}

With the dual aim of overcoming the dissociation, 'practical-theoretical contents learning', commonly assumed by teachers, and making in-service teachers aware of what students can learn (models) and feel, we make their own students experience scientific practices where hands-on and minds-on activities are developed in an integrated way.

Taking into account the recommendations for large-scale high school science reforms of adopting inquiry-based pedagogies in the science classroom, we assume it necessary to consider specially these teachers' perceptions explored before, which only widen the gap between the educational innovationresearch and the actual instruction.

We agree with the idea of engaging teachers in inquirí-based activities (with a learner's role) promotes the development of proper understandings of science and scientific inquiry, and the acceptance of science teaching approaches that involve children in questioning about phenomena and constructing explanations based on evidence (Haefner \& Zembal-Saul, 2004; Martínez-Chico, Jiménez-Liso, LópezGay \& Romero, 2018). Nevertheless, participation in professional development initiatives not always have the expected results in terms of change teachers ideas and practices, as sometimes their actual instruction does not change significantly (Correia \& Freire, 2016; Lee, Hart, Cuevas \& Enders, 2004). As many studies found, teachers find many difficulties to change their teaching conceptions consistent with the training programs and promoting practical work in their classrooms.

Something we cannot ignore, is the existing relationship between educational research and professional development if we want the innovations to become truly palpable in the current primary classes. As research has shown, when in-service teachers play an active role in innovation, these scenarios can become professional research scenarios themselves (Couso \& Pintó, 2009). Thus, it is necessary to include in-service teachers in the process of educational improvement, but always in a way that makes sense to them, making them consider these other alternative teaching approaches essential in their science lessons, making them realise all the advantages of scientific practices for their students learning.

Research has shown that inquiry-based teaching practices have a positive effect on student learning, particularly students' engagement in the cognitive dimensions of inquiry and teacher-led inquiry 
activities (Furtak, Seidel, Iverson \& Briggs, 2012). In the light of this scenario, a new interpretation of science teachers' training is required and new tools to evaluate and improve its effectiveness. This is what Sensociencia Project (@Sensociencia) focuses on.

To train competent teachers to promote scientific practices, we make science teachers experience inquiry and modelling cycles (SensoPills) and reflect about the process and what they feel to self-regulate their learning and emotions (Jiménez-Liso, Avraamidou, Martínez-Chico \& López-Gay, 2019). The designs are implemented and evaluated to test their efficacy and introduce improvements.

\subsection{Designed sequence supplied in "learning pill" format. Sensopill}

To reach our main goal (Science with Sense, Sensors \& Sensations, Jiménez-Liso, Avraamidou, MartínezChico \& López-Gay, 2019), we develop micro-sequences (1.5 hours) called Sensopills (SP) though a Model-based Inquiry (MBI) approach. In these SPs (Jiménez-Liso et al., 2019; Jiménez-Liso, MartínezChico \& Salmerón-Sánchez, 2018; Martínez-Chico, Evagorou \& Jiménez-Liso, 2019; Martínez-Chico et al., 2018), in-service teachers are engaged in scientific questions in contexts that make sense for them and promote to explicit their conceptions when formulating and justifying their hypothesis; they look for evidence to test their responses by using sensors to collect and show in-screen real time data (the sensors mainly used are measuring devices connected to the computer with free software that allows real-time graphics to visualize the evolution of the variables); results are analysed to review their initial explanations or models and adapt them to the new information, and then communicate their conclusions. All the activities are developed in an environment of communication, reflection, share and dialogue, debating about the process and considering alternative explanations.

As the competency 'explain phenomena scientifically' required for scientific literacy includes the ability to describe or interpret phenomena and predict changes what involve recognizing or identifying appropriate descriptions, explanations and predictions (National Research Council, 2015), SPs can include Inquiry cycles to construct descriptive knowledge, or Inquiry cycles to construct models than let explain and predict. The inquiry cycles in SPs vary depending on the kind of scientific knowledge we want to develop.

To facilitate the understanding of how we interpret this teaching approach (MBI), we outline the types of activities that characterize it in two cycles: inquiry and modelling cycles as it is common in other inquiry-based sequences (Pedaste et al., 2015). Sometimes the sequences follow an approach in which the focus is placed on the inquiry (Jiménez-Liso, Giménez-Caminero, Martínez-Chico, Castillo-Hernández \& López-Gay, 2019) including an engaging question, explicit expression of ideas, planning, evaluating or developing designs to obtain evidence, collecting data, analysing data to confirm or refute the initial ideas, getting and communicating conclusions. In other occasions the focus is on modelling (Garrido Espeja \& Couso Lagarón, 2017) where the purpose is put into the construction and evaluation of scientific school models.

The Sensopills designed were used in the training course with the teachers who answered the pre and post questionnaire (on practical works). These sequences, by combining hands on with minds on activities allow teachers to become aware that the practices are not only something manipulative but also serve to make the theory meaningful to their students, stablish connections to reality (the phenomenon) and build theoretical contents thanks to the evidence obtained through inquiry.

Furthermore, research has shown that emotions have an influence in many of the cognitive processes of learning-teaching, motivation and social interaction, so often, teachers are required to regulate their emotions. Moreover, many teachers find difficult to help in their students' emotions regulation and the 
overall emotional climate of the in their class (Fried, Mansfield \& Dobozy, 2015). Therefore, given the importance of training teachers to assist their students with their emotional regulation, and with the immediate intention of making our students to be aware of what they learn and feel when experiencing the activities, a self-regulation learning \& emotions activity is included at the end of each SP (JiménezLiso et al., 2018; Jiménez-Liso, Giménez-Caminero, Martínez-Chico, Castillo-Hernández \& López-Gay, 2019; Martínez-Chico et al., 2018, 2019).

\subsection{Post-training questionnaire results}

After implementing the SPs with the in-service teachers, we re-implemented the previously done questionnaire by themselves, in which they had the opportunity to identify from a series of factors that we showed them, those that they considered the most important target of the practical work.

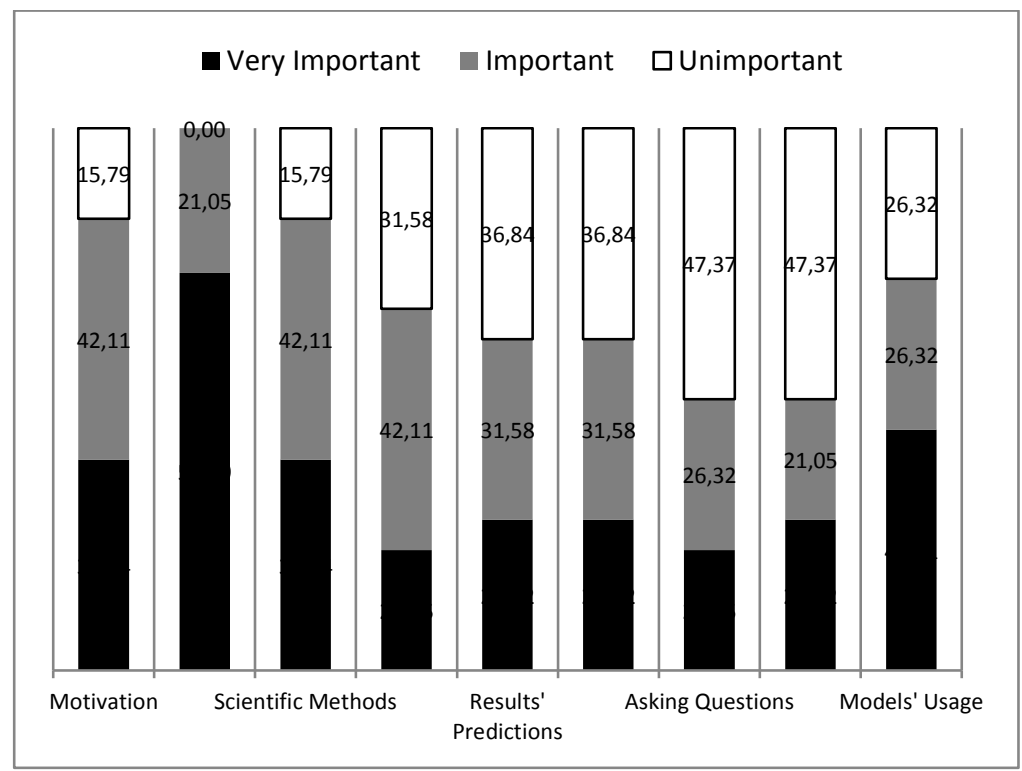

Figure 2. Importance that teachers attach to the purpose of practical works after experiencing the training course

The results obtained after the training course show the importance that in-service teachers give to the purposes to be achieved in scientific practices, after experiencing MBI sequences (Figure 2). This graph shows how the connection of the theory with the phenomenon becomes fully important for the inservice teachers. In addition, the use of models and the contents understanding that was previously valued as less important increase the importance with the development of scientific practices.

\section{Conclusions}

In this paper, the research questions Why are scientific practices not included in science classes? and What does it go unnoticed for teachers? Are addressed. To answer these questions, which are related, the results produced by the in-service teacher training course (extracted from a questionnaire) and the results of the case study (obtained from the interview and observation of the practice of a in-service secondary school teacher) have been combined.

Initially, the interviewed in-service teacher does not highlight the "theory" that is addressed when developing practical works, he does not consider these practices important to learn scientific theoretical contets. On one hand, this is due to he usually teaches these contents in the other kind of classes he 
develop, these are the regular and usual ones, following a more lecturing-style. In such classes the theoretical contents learning is something standard, so that it is not something remarkable for him.

Second, we have considered the results related to the importance that in-service teachers give to the targets of scientific practices, before and after experiencing Model-Based Inquiry learning sequences in a training course. The connection of the theoretical contents with the phenomenon becomes fully important for the in-service teachers, apart from attaching more importance to the use of models and contents understanding, initially valued as less important. This real connection theory-practice, this relationship between the theoretical contents and the phenomenon, makes the teachers conscious of the importance of the scientific practices to learn the scientific models that permit explain the phenomena. It seems that hands-on activities go to the background while the initial prominence given to minds on activities increases.

Definitely, one of the main results of this work is one of the causes of the lack of proper scientific practices in science classrooms: the theory-practice connection goes unnoticed by teachers. However, teachers highlight the students' motivation as the main purpose of scientific practices. By associating the success of scientific practices to external factors (students) and attitudes (motivation, often confused with hyperactivity), practical activities are perceived as being risky: So when the curriculum is causing pressure or when the novelty wears off, certainly scientific practices will be eliminated because they are seen as a waste of time and effort (without promoting learning).

Then, we focused on the teacher training, posing the question: How could we make teachers aware of the advantages of scientific practices to promote their incorporation into their instruction? In response to this question we opted for a Model-Based Inquiry approach to develop teacher training with SENSe, SENSors and SENSations for teachers to be aware and have proof of the advantages of the "inquirymodel-emotions" triangle. The Sensopills' evaluation described in previous papers (Jiménez-Liso et al., 2018, 2019; Martínez-Chico et al., 2018, 2019) let us to know more about the effectiveness of the sequence in achieving some of our desired goals of teacher training.

To face the usual dissociation "practical-learning conceptual contents" considered by teachers, we try to make them aware of the many advantages of scientific practices, for their potential to promote learning of theoretical content, for the models and the emotions that they produce. Moreover, we try to promote an evolution in their conceptions of science and science learning-teaching, as these conceptions determine the instruction they will develop in their classrooms. In order to develop this evolution, they experience leaning sequences that can be useful as methodological model to teach their future students.

Therefore, we can state that teachers reduce the scientific practices they perform in their classrooms because the inconveniences (lack of material and instruments, excessive time for preparation, high investment of time in their development, high student/teacher ratio, etc.), are not compensated for the main purpose they initially identify: hands on activities. However, when we carry out with them scientific practices focused on putting personal ideas and conceptions in conflict, by connecting the phenomenon and the model that explains it, these practices make sense for in-service teachers, and appreciate in them an added value: they promote learning of theoretical contents. Therefore, it can be seen as an opportunity for the incorporation of scientific practices into the classroom to be lasting. The implementation of Sensopills sequences in their context, with their own students, allows to show to inservice teachers' evidence about their students learning; hands-on skills, modelling skills, and the high students' engagement generated. In light of all this, we can conclude that according to these results we would be contributing to reduce the usual disconnection of practices with the theoretical contents learning, which remain the most important in science classes implicitly. Nevertheless, it is convenient to make a retrospective reflection and to exchange teachers' opinions to show us their point of view about 
their own instruction, co-working and the need to go forming teachers' networks stimulate feed-back and autonomy.

\section{References}

Alsop, S. \& Watts, M. (2003). Science education and affect. International Journal of Science Education, 25(9), 1043-1047. http://doi.org/10.1080/0950069032000052180

Ateş, Ö. \& Eryilmaz, A. (2011). Effectiveness of hands-on and minds-on activities on students' achievement and attitudes towards physics. Asia-Pacific Forum on Science Learning and Teaching, 12(1).

Boujaoude, S. B. \& Jurdak, M. E. (2010). Integrating physics and math through microcomputer-based laboratories (MBL): Effects on discourse type, quality, and mathematization. International Journal of Science and Mathematics Education, 8(3), 1019-1047. http://doi.org/10.1007/s10763-010-9219-2

Confederación de Sociedades Científicas de España. (2011). Informe ENCIENDE: Enseñanza de las Ciencias en la Didáctica Escolar para Edades Tempranas en España. Madrid: Rubes Editorial.

Correia, M. \& Freire, A. M. (2016). The influence of an in-service programme on primary teachers conceptions about practical work. Revista Electronica Interuniversitaria De Formacion Del Profesorado, 19(2), 259-272. http://doi.org/10.6018/reifop.19.2.254971

Couso, D. \& Pintó, R. (2009). Análisis del contenido del discurso cooperativo de los profesores de ciencias en contextos de innovación didáctica. Enseñanza de Las Ciencias, 27(1), 5-18.

Dávila Acedo, M. A., Borrachero Cortés, A. B., Cañada Cañada, F., Martínez Borreguero, G. \& Sánchez Martín, J. (2015). Evolución de las emociones que experimentan los estudiantes del grado de maestro en educación primaria, en didáctica de la materia y la energía. Eureka Sobre Enseñanza y Divulgación de Las Ciencias, 12(3), 550-564. http://doi.org/10498/17609

Duschl, R. A. \& Grandy, R. (2013). Two Views About Explicitly Teaching Nature of Science. Science \& Education, 22(9), 2109-2139. http://doi.org/10.1007/s11191-012-9539-4

Ebenezer, J., Kaya, O. N. \& Ebenezer, D. L. (2011). Engaging students in environmental research projects: Perceptions of fluency with innovative technologies and levels of scientific inquiry abilities. Journal of Research in Science Teaching, 48(1), 94-116. http://doi.org/10.1002/tea.20387

Evagorou, M., Nicolaou, C. T. \& Lymbouridou, C. (2014). Elementary school students' emotions and engagement: Using models and SSI as a context of instruction in Science. Journal of Research in Science Teaching.

Fried, L., Mansfield, C. \& Dobozy, E. (2015). Teacher emotion research: Introducing a conceptual model to guide future research. Ssues in Educational Research, 25(4), 415-442.

Furtak, E. M., Seidel, T., Iverson, H. \& Briggs, D. C. (2012). Experimental and Quasi-Experimental Studies of Inquiry-Based Science Teaching: A Meta-Analysis. Review of Educational Research, 82(3), 300-329. http://doi.org/10.3102/0034654312457206 
Haefner, L. A. \& Zembal-Saul, C. (2004). Learning by doing? Prospective elementary teachers' developing understandings of scientific inquiry and science teaching and learning. International Journal of Science Education, 26(13), 1653-1674. http://doi.org/10.1080/0950069042000230709

Hazelkorn, E., Ryan, C., Beernaert, Y., Constantinous, C. P., Deca, L., Grangeat, M., ... Welzel-Breuer, M. (2015). Science Education for Responsible Citizenship. Directorate-General for Research and Innovation Science with and for Society. Retrieved from http://ec.europa.eu/research/swafs/pdf/pub_science_education/KI-NA-26-893-EN-N.pdf

Holstermann, N., Grube, D. \& Bögeholz, S. (2010). Hands-on Activities and Their Influence on Students' Interest. Research in Science Education, 40(5), 743-757. http://doi.org/10.1007/s11165-009-9142-0

Jiménez-Liso, M. R., Avraamidou, L., Martínez-Chico, M. \& López-Gay, R. (2019). Scientific Practices in Teacher Education: The interplay of sense, sensors, and emotions. Research in Science \& Technological Education, in press.

Jiménez-Liso, M. R., Martínez-Chico, M. \& Salmerón-Sánchez, E. (2018). Chewing Gum and pH Level of the Mouth: A Model-based Inquiry Sequence to Promote Scientific Practices. World Journal of Chemical Education, 6(3). http://doi.org/10.12691/wjce-6-x-x

Jiménez-Liso, M.R., Giménez-Caminero, E., Martínez-Chico, M., Castillo-Hernández, F. J. \& López-Gay, R. (2019). El enfoque de enseñanza por indagación ayuda a diseñar secuencias: ¿Una rama es un ser vivo? In J. Solbes \& M. R. Jiménez-Liso (Eds.), Propuestas de educación científica basadas en la indagación y modelización en contexto. Valencia: Tirant lo blanch.

Lee, O., Hart, J. E., Cuevas, P. \& Enders, C. (2004). Professional development in inquiry-based science for elementary teachers of diverse student groups. Journal of Research in Science Teaching, 41(10), 10211043. http://doi.org/10.1002/tea.20037

Martínez-Chico, M., Evagorou, M. \& Jiménez-Liso, M. R. (2019). Design of a pre-service teacher training unit to promote scientific practices. Is a chickpea a living being? International Journal of Desings for Learning, 10(1), in press.

Martínez-Chico, M., Jiménez-Liso, M. R., López-Gay, R. \& Romero, M. (2018). Inquiry and modeling in pre-service teacher training to improve scientific, epistemic, pedagogical knowledge, and emotional selfregulation. In O. Finlayson, E. McLoughlin, S. Erduran, \& P. Childs (Eds.), Research, Practice and Collaboration in Science Education (Proceedings of ESERA 2017) (pp. 1763-1772). Dublin, Ireland: Dublin City University. Retrieved from https://www.esera.org/publications/esera-conferenceproceedings/esera-2017

Mellado Jiménez, V., Borrachero Cortés, A. B., Brígido Mero, M., Melo, L. V., Dávila Acedo, M. A., Cañada Cañada, F., ... Sánchez, J. (2014). Las emociones en la enseñanza de las ciencias. Enseñanza de Las Ciencias, 32(3), 11-36. http://doi.org/10.5565/rev/ensciencias.1478

National Research Council. (2012). A Framework for K-12 Science Education. A Framework for K-12 Science Education: Practices, Croscutting Concepts, and Core Ideas. (Vol. 1). http://doi.org/10.17226/13165

National Research Council. (2015). Science Teachers' Learning. (H. Schweingruber \& N. Nielsen, Eds.). Washington, D.C.: National Academies Press. http://doi.org/10.17226/21836 
Nicolaou, C. T., Evagorou, M. \& Lymbouridou, C. (2015). Elementary School Students' Emotions when Exploring an Authentic Socio-Scientific Issue through the Use of Models. Science Education International, 26(2), 240-259.

Osborne, J. (2014). Scientific Practices and Inquiry in the Science Classroom. In N. G. Lederman (Ed.), Handbook of Research on Science Education, Volume II (pp. 579-599). Mawah, NJ: Lawrence Erlbaum Associates Publishers. http://doi.org/10.4324/9780203097267.ch29

Pino Álvarez, A., Jiménez Valladares, J. de D., Jiménez Liso, M. R. \& Sampedro Villasán, C. (2012). Experimenta, a science teacher training program in CBLIS. In International Conference on Computer Based Learning in Science (CBLIS) (pp. 58-66). Retrieved from http://cblis2012.crecim.cat/

Rocard, M., Csermely, P., Jorde, D., Walberg-Henriksson, H. \& Hemmo, V. (2007). A Renewed Pedagogy for the Future of Europe (Report EU22-845, Brussels, 2007). (P. McLaren \& J. Giarelly, Eds.). DirectorateGeneral for Research Science, Economy and Society.

Thagard, P. (2008). Conceptual change in the history of science: life, mind and disease. In S. Vosniadou (Ed.), International Handbook of Research on Conceptual Change (pp. 374-387). New York: Routledge. 